\title{
Impact of Organizational Culture on Innovative Work Behavior
}

\author{
Miran Sardar \\ Tishk International University, Sulaymaniyah Campus, Iraq \\ Business and Management Department \\ miran.sardar@std.tiu.edu.iq \\ Tazhan Mahdi \\ Tishk International University, Sulaymaniyah Campus, Iraq \\ Business and Management Department \\ tazhan.mahdi@std.tiu.edu.iq
}

DOI: 10.47299/bsjmm.v1i2.57

\begin{abstract}
'Organization' is an important tool that helps us organize both goods and services we need to sustain our lives in better quality. Managers and employees in a company struggle to use that tool in a suitable way to increase their success in the market to be able to survive in the long term. This paper aimed to investigate the effectiveness of an organization in terms of training, co-workers, and supervisor support in this respect. The results revealed that 'training' was the strongest influencer on the innovative work behavior of employees at various firms in the region. Secondly, the impact of 'supervisor support' on innovative work behavior was significant. Lastly, the impact of 'co-worker support' was also significant but weaker compared to the other two variables.
\end{abstract}

Keywords: Organizational culture, socialization, co-worker support, supervisor support, innovative work behavior, Kurdistan, Iraq

\section{Introduction}

Organization is a tool through which a group of people try to achieve specific goals together (Budur \& Demir, 2019). The most important part in this definition is the 'group of people' and 'specific goals' because lack of personnel coordination may lead to failure in reaching desired objectives (Mohammed et al., 2020; Poturak et al., 2020). After realizing the importance of people, researchers noted that the success of the company depends on the motivation of employees, something which increases employee performance and quality customer relationship (Demir et al., 2019). Accordingly, high motivation of the employees has a positive impact on the customers that maintain the companies' long-term existence (Top et al., 2020; Yildiz \& Amin, 2020)

Furthermore, a great part of management consists of collecting relevant data in order to make people more effective and skillful in reaching their goals (Budur, 2018). Managers are supposed to bring those elements together to establish a produce value for the society (Demir \& Budur, 2019). In this respect, one of the crucial questions of the management science, "why do organizations exist?", could be answered in two ways (Hilal \& Top, 2019; Mohammed \& Sahin, 2020): on the one hand, companies operate to accomplish optimal targets as they produce value for the society and succeed for themselves (Budur et al., 2018); on the other hand, they improve employee and consumer satisfaction as they offer professional services and goods (Rashid, 2018; Sahin, 2014).

To reach desired objectives, organizations have to train and improve the abilities of their employees to adapt to the changing environment (Budur \& Poturak, 2020; Mohammed et al., 2020). This process 
could be described as socialization through which organizations teaches its rules, norms and culture to the new employees that they hire (Jones, 2013). Besides, socialization is a crucial policy of businesses that has a positive impact on employee performance and organizational effectiveness to deal with uncertainties (Chao, 1994).

Furthermore, it has been noted that socialization and employees' innovative behavior in the workplace are closely related to each other (Ashforth et al., 2007). Innovative work behavior means any new or creative idea which makes a positive change in the workplace (Wynen et al., 2020). Scholars argue that innovative behaviors that increase the motivation and performance within the organization is significantly triggered by leadership behavior, organizational culture, rewarding, and socialization tactics (Budur \& Poturak, 2021; Moyson et al., 2018; Torlak et al., 2021; Zaim et al, 2020).

Consequently, based on the aforementioned positive correlations between the socialization processes and innovative work behavior, this paper aimed to investigate the association mentioned above among the Kurdish companies in Sulaymaniyah, Kurdistan Region of Iraq. Kurdistan is an emerging market that becomes a focal point for different small and medium sized investigations from the neighborhood and European countries (Budur \& Poturak, 2021; Demir et al., 2021). In this regard, managers should apply successful strategies to leverage employee motivation and customer satisfaction to survive in the long term. Socialization tactics and innovation in the organization have crucial roles in the process accordingly.

\section{Literature View}

\section{Organizational Culture and Training}

"Organizational culture is the set of shared values and norms that controls organizational members' interactions with each other and with suppliers, customers, and other people outside the organization." (Jones, 2013, p.31). The culture in the organization shapes its identity in the market (Zardasht et al., 2020). Besides, an effective management that focuses on the employee motivation has a strong impact on HRM to improve performance-based training policies (Faeq, 2020; Zaim et al., 2020; Demir, 2020a). From these points of view, the corporate culture fosters employee attitudes inside, and the responses outside the company has significant impact on its effectiveness by promoting employee performance and customer favorable outcomes (Ahmed, 2020; Budur et al., 2019; Demir, 2020b).

Training is a process and a tool of HRM departments to socialize and educate employees according to the requirements of the new environment in order to boost the competitiveness of the organization (Budur \& Poturak, 2020; Demir et al., 2020). Based on the requirements, HR teams should focus on the capabilities of the staff in order to find suitable training programs for efficiency (Ali et al., 2020; Khan \& Yildiz, 2020; Demir, 2019). Organizations mainly use socialization tactics for two reasons: (a) focusing on the new comers to teach attitudes, skills and behaviors that are required to finish tasks effectively and (b) training the current workers to improve their skills (Jones, 2013; Demir \& Bulut, 2018; Bayiz Ahmed et al., 2019).

\section{Co-Worker and Supervisor Support for Innovation}

A co-worker is not like any other individual in the company. A co-worker is absolutely the nearest person with whom an employee spends most of the work time (Abdulla et al., 2020; Durmaz, 2017). 
Favorable behaviors such as helping others, altruism, courtesy, and civic virtue are some of the good citizenship behaviors in the organizations that support quality of interaction among peers (Budur \& Porturak, 2020; 2021). Consequently, these behaviors have a positive impact on employee performance (Altun, 2017; Kamal \& Shawkat, 2020; Yildiz \& Celik, 2017).

On the other hand, we do not exactly know how co-worker and/or supervisor support help produce the desired outcomes on the employee (Yildiz \& Budur, 2019). Researchers argue that supervisors affect employee motivation and performance in the workplace to a great extent (Al-Abrrow, 2014; 2018). Besides, Hammer et al. (2019) found that training programs for the supervisors and their staff support are positively influential on employee outcomes.

\section{Methodology}

Sampling

The sampling utilized for the study covered 202 participants who were selected based on simple random sampling methodology from 32 organizations in the Kurdistan Region of Iraq. The questionnaire was in English language and was translated into Kurdish as well for clarification.

\section{Participants}

The participants were $36 \%$ female and $64 \%$ male. Their educational levels were: $26 \%$ high school, $7 \%$ vocational school, $2 \%$ institute, $54 \%$ university. Their positions were: $38 \%$ entry level employee, $2 \%$ expert, $4 \%$ middle level manager, $6 \%$ director, $1 \%$ specialist, $8 \%$ manager, and $2 \%$ general manager.

\section{Procedures}

We utilized simple random sampling method and visited different companies in the region. Because the questionnaire addressed different educational levels, it was translated into Kurdish language to improve the understanding and satisfaction. The respondents were asked to fill out the questionnaire in person so that they could ask the interviewer if they needed clarification at any point.

\section{Measures}

The questionnaire focused on 3 main variables: training, understanding, and innovative work behavior. There were 19 questions in the questionnaire: 5 questions for training, 5 for understanding, and 9 for innovative culture. Training and understanding questions were rated based on Likert's Scale: 1 meaning strongly disagree, 2 disagree, 3 neutral, 4 agree and 5 strongly agree. 'Innovative work behavior' questions were rated based on Likert's Scale: 1 never, 2 sometimes, 3 regularly, 4 often, 5 always.

The hypotheses were:

H1: Training has a positive impact on innovative work behavior

H2: Co-worker support has a positive impact on innovative work behavior

H3: Supervisor support has a positive impact on innovative work behavior 


\section{Research Findings}

Hypothesis Testing

Each hypothesis has been tested in two ways: correlation analysis and then regression analysis. Correlation is used to signify the association between two quantitative variables while (linear) regression is used to estimate the best straight line to summarize the association. Correlation assumes there is a linear relationship between the two variables and it also describes the strength of an association between two variables.

\section{Figure 1 Model of the study}

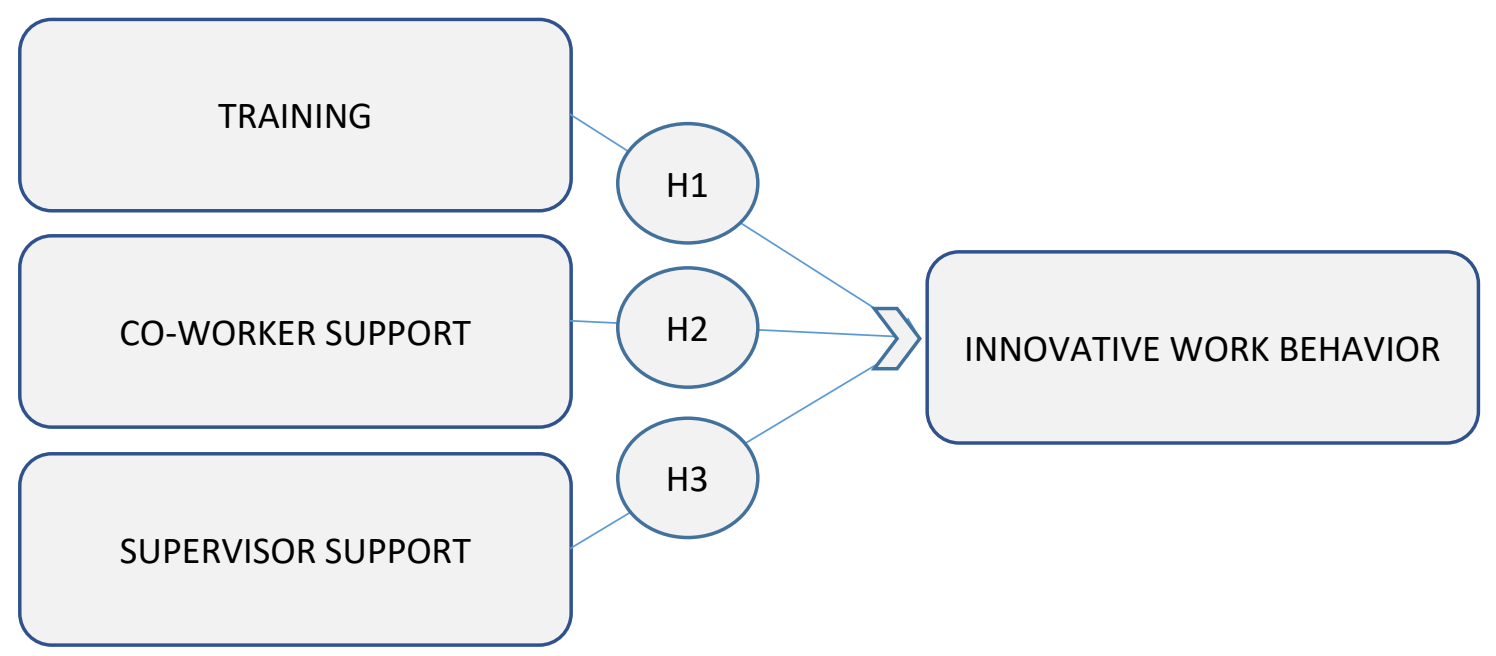

It is symmetrical, i.e. the correlation between $A$ and $B$ is the same as the correlation between $B$ and $A$. For regression: if two variables are related, it means that when one changes by a certain amount, the other changes on an average by a certain amount as well. If $y$ represents the dependent variable and $x$ the independent variable, the relationship is described as the regression of $y$ on $x$. Regression simply means that the average value of $y$ is a function of $x$, i.e. it changes with $x$. Regression equation is often more useful than the correlation coefficient. It enables us to predict $\mathrm{y}$ from $\mathrm{x}$ and gives us a better summary of the relationship between the two variables.

Table 1 shows the results of covariance and correlation analysis among training, co-worker support, supervisor support and innovative work behavior.

Table 1 Covariance and correlation relations

\begin{tabular}{llcc}
\hline Variable I & Variable II & covariance & correlation \\
\hline Training & Innovative work behavior & 0.33 & 0.48 \\
Co-worker support & Innovative work behavior & 0.23 & 0.33 \\
Supervisor support & Innovative work behavior & 0.23 & 0.31 \\
\hline
\end{tabular}

It was observed that there is a weak correlation between the coworker support and innovative behavior as well as supervisor support and innovative work behavior. Besides, there is a moderate correlation between training and innovative work behavior. Based on these results, it can be revealed 
that training is more correlated with the innovative work behavior than supervisor and coworker supports.

Regression analysis is an important tool which establishes a connection between at least two variables. There is numerical source in regression analysis which analyzes the impact of at least one autonomous factor on a dependent variable. $R$ square is the indicator which shows the causation of the independent variable on the dependent one.

Table 2 shows that training has a significant impact on innovative work behavior (as $t$ statistics is greater than 1.96). It explains $23 \%$ of the overall variance on innovative work behavior.

Table 2 Regression analysis

\begin{tabular}{llcccccc}
\hline Independent variable & \multicolumn{2}{l}{ Depended variable } & r square & $\begin{array}{c}\text { adjustment } \\
\text { R square }\end{array}$ & t stat & $\begin{array}{c}\text { co- } \\
\text { efficient }\end{array}$ & Result \\
\hline H1 training & $\begin{array}{l}\text { innovative } \\
\text { behavior }\end{array}$ & work & 0.23 & 0.22 & 7.65 & 0.60 & significant \\
H2 co-worker support & $\begin{array}{l}\text { innovative } \\
\text { behavior }\end{array}$ & work & 0.10 & 0.09 & 4.66 & 0.37 & significant \\
H3 supervisor support & $\begin{array}{l}\text { innovative } \\
\text { behavior }\end{array}$ & work & 0.21 & 0.21 & 7.31 & 0.52 & significant \\
\hline
\end{tabular}

Moreover, supervisor support is the second variable which explains $21 \%$ of the overall variance on innovative work behavior. Lastly, although it was statistically significant, the impact of co-worker support was weaker in variance (10\%) compared to the other independent variables.

The results of regression analysis support the results given in the correlation analysis. In both analyses, it was revealed that training was the main element which initiated the innovative work behavior rather than co-worker support and supervisor support. Apart from the impact of training, regression analysis further elaborated the impact of co-worker support and supervisor support. It was revealed that supervisor support was more influential on innovative work behavior more than co-worker support was.

\section{Conclusion}

The study attempted to understand how to make employees in an organization more innovative in the Kurdistan Region of Iraq as low levels of observed innovativeness and commitment in organizations prevailed.

We analyzed how co-worker support, supervisor support, and training can affect the innovative work behavior of the employees. In this context, 201 questionnaires were collected from the employees of various companies in the region. The results were analyzed using correlation analysis and regression analysis.

The results of the regression analysis showed that training is the most affective factor on innovative work behavior compared to support of supervisor or the coworker support. We concluded that the organizations do not seem to pay attention to the issue of training.

Based on the results, we suggest that the managers of the firms need to plan trainings for the employees in order to increase their innovative work behavior. Secondly, the supervisors need to 
show their support to employees and motivate them to work innovatively in their jobs. Lastly, the firms should organize social activities periodically in order to socialize their employees, which in return will make the employees feel more motivated to work innovatively.

\section{Limitations}

The data and corresponding analyses are limited to the Kurdistan Region of Iraq. Any change in the location will certainly call for new data to be collected.

\section{References}

Abdulla, N., Wrya, H., \& Durmaz, O. (2020). Green product perception in Kurdistan Region of Iraq. Black Sea Journal of Management and Marketing, 1(1), 1-15.

Ahmed, M. A. (2020). Market segmentation of diet nutrition supply for the new entrepreneurs: Case study in Kurdistan Region of Iraq. Black Sea Journal of Management and Marketing, 1(1), 17-28.

AL-Abrrow, H. A. (2018). The effect of perceived organisational politics on organisational silence through organisational cynicism: Moderator role of perceived support. Journal of Management \& Organization, 1-20.

Al-Abrrow, H. A. W. (2014). Transformational leadership and organisational performance in the public healthcare sector: The role of organisational learning and intellectual capital. Irish Journal of Management, 33(1), 27.

Ali, S. H. K., Khan, N. S., \& Yildiz, Y. (2020). Leadership effects on CSR employee, media, customer, and NGOs. Management and Economics Research Journal, 6, Article ID 961566.

Altun, M. (2017). The effects of teacher commitment on student achievement: A case study in Iraq. International Journal of Academic Research in Business and Social Sciences, 7(11), 417-426.

Ashforth, B. E., Sluss, D. M., \& Saks, A. M. (2007). Socialization tactics, proactive behavior, and newcomer learning: Integrating socialization models. Journal of Vocational Behavior, 70(3), 447-462.

Bayiz Ahmad, A., Liu, B., \& Saleem Butt, A. (2019). Predictors and outcomes of change recipient proactivity in public organizations of the Kurdistan Region of Iraq. International Public Management Journal, 1-29.

Budur, T. (2018a). Analytic Hierarchy Process to evaluate corporate image, trust, and switching cost of GSM operators: A case of Kurdistan Region of Iraq. International Journal of Social Sciences \& Educational Studies, 5(2), 241-250

Budur, T. (2018b). The impact of Al-Ghazali's virtues on organizational commitment and performance: A case study at private education institutions in Kurdistan Region of Iraq. ICABEP, Erbil-Iraq, 2, p21.

Budur, T., \& Demir, A. (2019a). Leadership effects on employee perception about CSR in Kurdistan Region of Iraq. International Journal of Social Sciences \& Educational Studies, 6(1). 142-154.

Budur, T., \& Demir, A. (2019b). Leadership perceptions based on gender, experience, and education. International Journal of Social Sciences \& Educational Studies, 6(1), 142-154.

Budur, T., \& Poturak, M. (2020). Transformational leadership and its impact on customer satisfaction. Measuring Mediating effects of organizational citizenship behaviors. Middle East Journal of Management.

Budur, T., \& Poturak, M. (2021). Employee performance and customer loyalty: Mediation effect of customer satisfaction. Middle East Journal of Management.

Budur, T., Faraj, K. M., \& Karim, L. A. (2019). Benchmarking operations strategies via hybrid model: A case study of caférestaurant sector. Amazonia Investiga, 8, 842-854.

Budur, T., Rashid, C. A., \& Poturak, M. (2018). Students' perceptions on university selection, decision making process: A case study in Kurdistan Region of Iraq. International Journal of Social Sciences \& Educational Studies, 5(1), 133-144.

Chao, G. T.-K. (1994). Organizational socialization: Its content and consequences. Retrieved from https://psycnet.apa.org/doi/10.1037/0021-9010.79.5.730 
Demir, A., Shawkat, S., Majeed, B.N., \& Budur, T. (2019). Fuzzy AHP and VIKOR to select best location for bank investment: case study in Kurdistan Region of Iraq. In Effective Investments on Capital Markets, Tarczyn'sk W, Nermend K (eds). Springer: Cham; 485-510.

Demir, A. (2019). The impact of strategic operations management decisions on shoppers' wellbeing. Asian Academy of Management Journal, 24(1).

Demir, A. (2020b). InterContinental review for diffusion rate and internal-external benefits of ISO 9000 QMS. International Journal of Productivity and Quality Management. DOI: 10.1504/IJPQM.2020.10030912

Demir, A., \& Budur, T. (2019). Roles of leadership styles in corporate social responsibility to non-governmental organizations (NGOs). International Journal of Social Sciences \& Educational Studies, 5(4), 174-183.

Demir, A., (2020a). Impact of internal marketing on the customer perceptions in SMEs. International Journal of Services and Operations Management. DOI: 10.1504/IJPQM.2020.10030912

Demir, A. (2020b). Inter-continental review for diffusion rate and internal-external benefits of ISO 9000 QMS. International Journal of Productivity and Quality Management.

Demir, A., Budur, T., \& Heshmati, A. (2020). Antecedents of trust, corporate image, and switching costs: a case in telecommunication services in the Kurdistan region of Iraq. International Journal of Mobile Communications, 19(1), 5374. DOI: $10.1504 / \mathrm{IJMC} .2021 .10030758$

Demir, A., Maroof, L., Khan, N. U. S., \& Ali, B. J. (2020). The role of E-service quality in shaping online meeting platforms: a case study from higher education sector. Journal of Applied Research in Higher Education. DOI: 10.1108/JARHE-082020-0253

Demir, A., Budur, T., Hiwa, M., \& Heshmati, A. (2021). Links between Knowledge Management and Organizational Sustainability: Does the ISO 9001 certification have an effect? Knowledge Management Research \& Practice (TKMR), Doi: $10.1080 / 14778238.2020 .1860663$

Durmaz, O. (2017). Investigation of the motivation parameters in health care establishments. International Journal of Social Sciences \& Educational Studies, 3(4), 44.

Faeq, M. (2020). Performance evaluation criteria development process for academic staff at universities. Black Sea Journal of Management and Marketing, 1(1), 59-70.

Hammer, L. B., Wan, W. H., Brockwood, K. J., Bodner, T., \& Mohr, C. D. (2019). Supervisor support training effects on veteran health and work outcomes in the civilian workplace. Journal of Applied Psychology, 104(1), 52.

Hilal, D., \& Top, C. (2019). Impact of product and service quality of gated communities on the repurchase intentions: A case study in Kurdistan Region of Iraq. International Journal of Economics, Commerce and Management, 7(6)505-515.

Jones, G. R. (2013). Organizational theory, design, and change. Upper Saddle River, NJ: Pearson.

Kamal, T., \& Shawkat, S. (2020). The impact of dynamic capabilities on knowledge management in Kurdistan Region of Iraq. Black Sea Journal of Management and Marketing, 1(1), 41-48.

Khan, N. U. S., \& Yildiz, Y. (2020). Impact of intangible characteristics of universities on student satisfaction. Amazonia Investiga, 9(26), 105-116.

Mete, E. S. (2017). The Path extended from organizational culture to innovative work behavior: A research on a defense company. İşletme Araştırmaları Dergisi, 9(1), 403-428.

Mohammed, K. S., Rashid, C. A., Salih, H. A., \& Budur, T. (2020). The role of online teaching tools on the perception of the students during the lockdown of Covid-19. International Journal of Social Sciences \& Educational Studies, 7(3), 178-190.

Mohammed, S. S., \& Shahin, O. (2020). Service quality perspectives in telecommunication sector: Trust and Loyalty Investigation. Amazonia Investiga, 9(28), 394-403.

Mohammed, S. S., Suleyman, C., \& Taylan, B. (2020). Burnout determinants and consequences among university lecturers. Amazonia Investiga, 9(27), 13-24. 
Moyson, S., Raaphorst, N., Groeneveld, S., \& Van de Walle, S. (2018). Organizational socialization in public administration research: A systematic review and directions for future research. The American Review of Public Administration, 48(6), 610-627.

Poturak, M., Mekić, E., Hadžiahmetović, N., \& Budur, T. (2020). Effectiveness of Transformational Leadership among Different Cultures. International Journal of Social Sciences \& Educational Studies, 7(3), 119-129.

Rashid, C. A. (2018). Efficiency of financial ratios analysis for evaluating companies' liquidity. International Journal of Social Sciences \& Educational Studies, 4(4), 110.

Sahin, O. (2014). An investigation of student satisfaction factors. Journal of Research in Business and Management, 2(6), 81.

Taormina, R. J. (2004). Convergent validation of two measures of organizational socialization. The International Journal of Human Resource Management, 15(1), 76-94.

Top, C., Abdullah, B. M. S., \& Faraj, A. H. M. (2020). Transformational leadership impact on employees' performance. Eurasian Journal of Management \& Social Sciences. 1(1), 49-59

Torlak, N. G., Demir, A., \& Budur, T. (2019). Impact of operations management strategies on customer satisfaction and behavioral intentions at café-restaurants. International Journal of Productivity and Performance Management.

Torlak, N. G., Kuzey, C., Dinc, MS., \& Budur, T. (2021). Links connecting nurses' planned behavior, burnout, job satisfaction and organizational citizenship behavior. Journal of Workplace Behavioral Health. Doi:10.1080/15555240.2020.1862675

Woo, B., \& Chelladurai, P. (2012). Dynamics of perceived support and work attitudes: The case of fitness club employees. Human Resource Management Research, 2(1), 6-18.

Wynen, J., Boon, J., Kleizen, B., \& Verhoest, K. (2020). How multiple organizational changes shape managerial support for innovative work behavior: Evidence from the Australian Public Service. Review of Public Personnel Administration, 40(3), 491-515.

Yildiz, Y., \& Amin, H. H. H. (2020). Impact of organizational citizenship behaviour on customer satisfaction. Eurasian Journal of Management \& Social Sciences. 1(1), 17-35

Yildiz, Y., \& Budur, T. (2019). Introducing environmental awareness to college students with curricular and extracurricular activities. International Journal of Academic Research in Business and Social Sciences, 9(3)667-675.

Yildiz, Y., \& Celik, B. (2017). Commitment to the teaching profession. International Journal of Social Sciences \& Educational Studies, 4(2), 93.

Zaim, H., Demir, A., \& Budur, T. (2020). Ethical leadership, effectiveness and team performance: An Islamic Perspective. Middle East Journal of Management.

Zardasht, P., Omed, S., \& Taha, S. (2020). Importance of HRM policies on employee job satisfaction. Black Sea Journal of Management and Marketing, 1(1), 49-57. 


\section{Appendix}

\section{Demographic Information}

Company name:

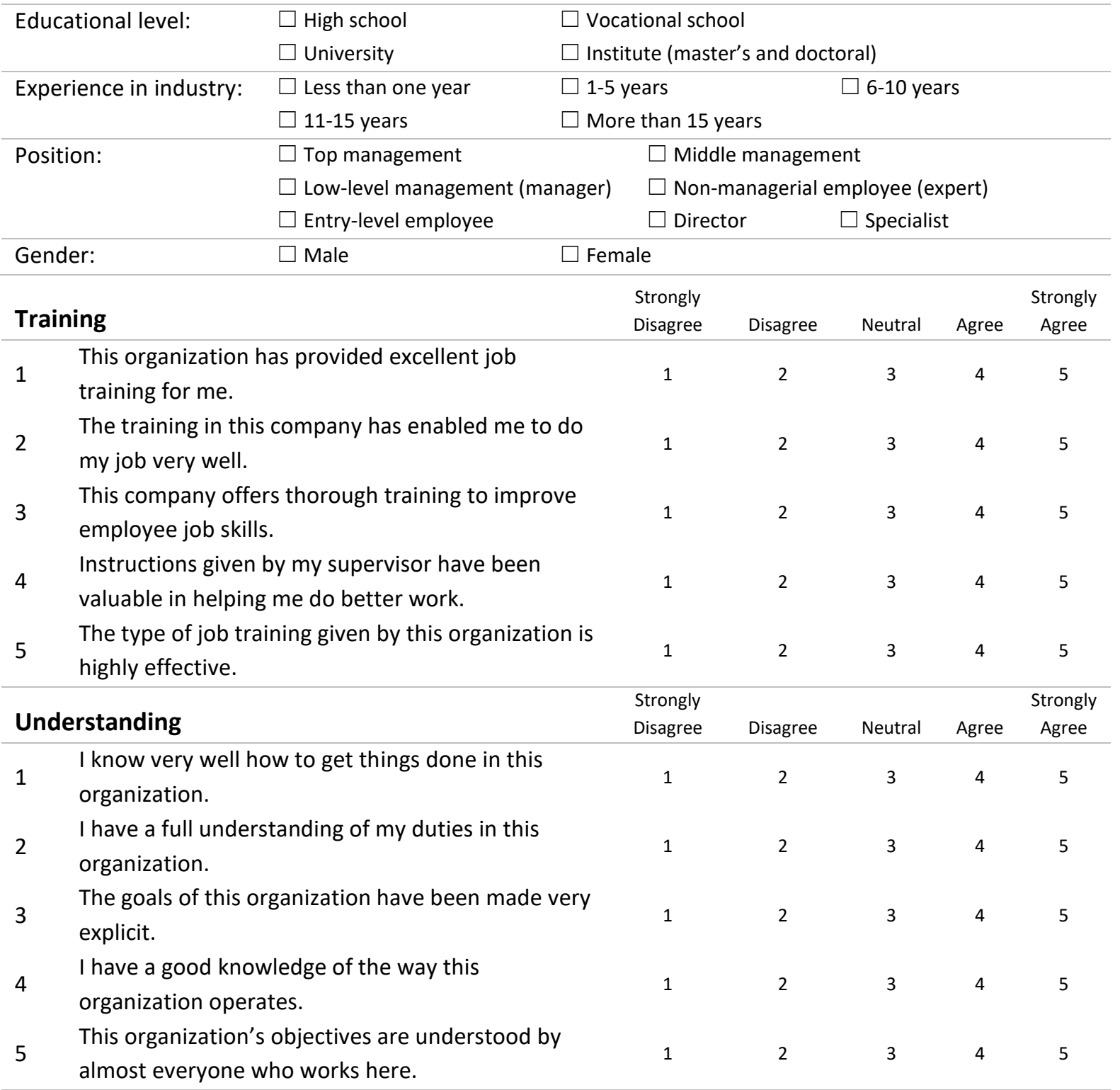

\section{Innovative Work Behavior}

$\begin{array}{ccccc}\text { Never } & \text { Sometimes } & \text { Regularly } & \text { Often } & \text { Always } \\ 1 & 2 & 3 & 4 & 5 \\ 1 & 2 & 3 & 4 & 5 \\ 1 & 2 & 3 & 4 & 5 \\ 1 & 2 & 3 & 4 & 5 \\ 1 & 2 & 3 & 4 & 5 \\ 1 & 2 & 3 & 4 & 5\end{array}$

Creating new ideas for improvements

Searching out new working-methods, techniques,

2 or instruments

3 Generating original solutions for problems

$4 \quad$ Mobilizing support for innovative ideas

$5 \quad$ Acquiring approval for innovative ideas

Making important organizational members enthusiastic for innovative ideas 
20 Black Sea Journal of Management and Marketing 1(2), 2020

7

Transforming innovative ideas into useful applications

8 Introducing innovative ideas into the work environment in a systematic way
1
2

2
3

45

$4 \quad 5$

$4 \quad 5$

